
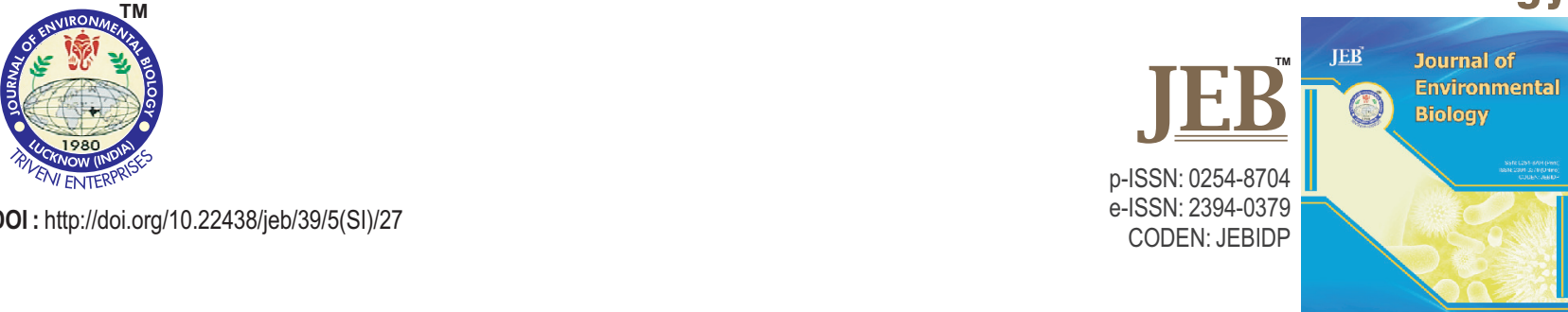

\title{
Mouth morphological development of Hilsa (Tenualosa ilisha) larvae collected from Meghna Estuary, Bangladesh
}

\section{Authors Info \\ Md. G.S. Riar', R. Ara', S.M.N. Amin', Mohd. S. Kamarudin', Md. A. Wahab', Nur- A- Raushon ${ }^{3}$, J. Arockiaraj and A. Arshad"* \\ ${ }^{1}$ Laboratory of Fisheries Biology and Aquatic Ecology, Department of Aquaculture, Faculty of Agriculture, Universiti Putra Malaysia, 43400 UPM, Serdang, Selangor, Malaysia ${ }^{2}$ ECOFISH-BD, WorldFish, South Asia, Bangladesh, Banani, Dhaka 1213, Bangladesh \\ ${ }^{3}$ Bangladesh Fisheries Research Institute, Mymensingh, 2201, Bangladesh \\ ${ }^{4}$ Faculty of Science and Humanities, SRM University, Kattankulathur - 603 203, India \\ *Corresponding Author Email : azizar.upm@gmail.com}

Key words

Early juvenile

Flexion stage

Jaw length

Mouth gape

Tenualosa ilisha

Publication Info

Paper received : 10.06.2017

Revised received : 21.10.2017

Re-revised received : 15.11.2017

Accepted : 28.12.2017

\begin{abstract}
Aim: In larval fish, food size is closely related with the length of the fish jaw, as well as mouth gape. So far, no information is available on the larval mouth morphology of Hilsa shad Tenualosa ilisha. Hence, observations on the mouth morphological development during different larval stages of $T$. ilisha were examined.
\end{abstract}

Methodology: Samples of T. ilisha larvae were collected weekly from Meghna estuary, Bangladesh between August 2016 and January 2017. The collected samples were transported to the laboratory and the mouth morphology of larvae and early juvenile stages were microscopically examined.

Results: The smallest mouth size was found at $45^{\circ}$, while was largest found was at $90^{\circ}$. There was no evidence of teeth, while the lower jaw was longer than the upper jaw. The four larval stages were observed in this study; viz. yolk-sack stage, preflexion stage, flexion stage, postflexion stage. The mouth was closed at yolk sac stage while in the preflexion stage, larval mouth gape ranged between 177 and $367 \mu \mathrm{m}$. In the flexion stage, the range was 241 to $497 \mu \mathrm{m}$, in post-flexion stage it ranged between 307 and $621 \mu \mathrm{m}$ and finally in early juvenile stage the range was 393 to $788 \mu \mathrm{m}$.

Interpretation: There was a significant relationship with standard length (SL) and upper jaw length $\left(R^{2}\right.$ $=0.941, p<0.05)$ as well as lower jaw $\left(R^{2}=0.931, p<0.05\right)$. Significant relationship was also found with $\mathrm{SL}$ and mouth gap at $90^{\circ}\left(R^{2}=0.938, p<\right.$ $0.05)$. Overall, these findings can be considered a base data for mouth morphological development of $T$. ilisha.

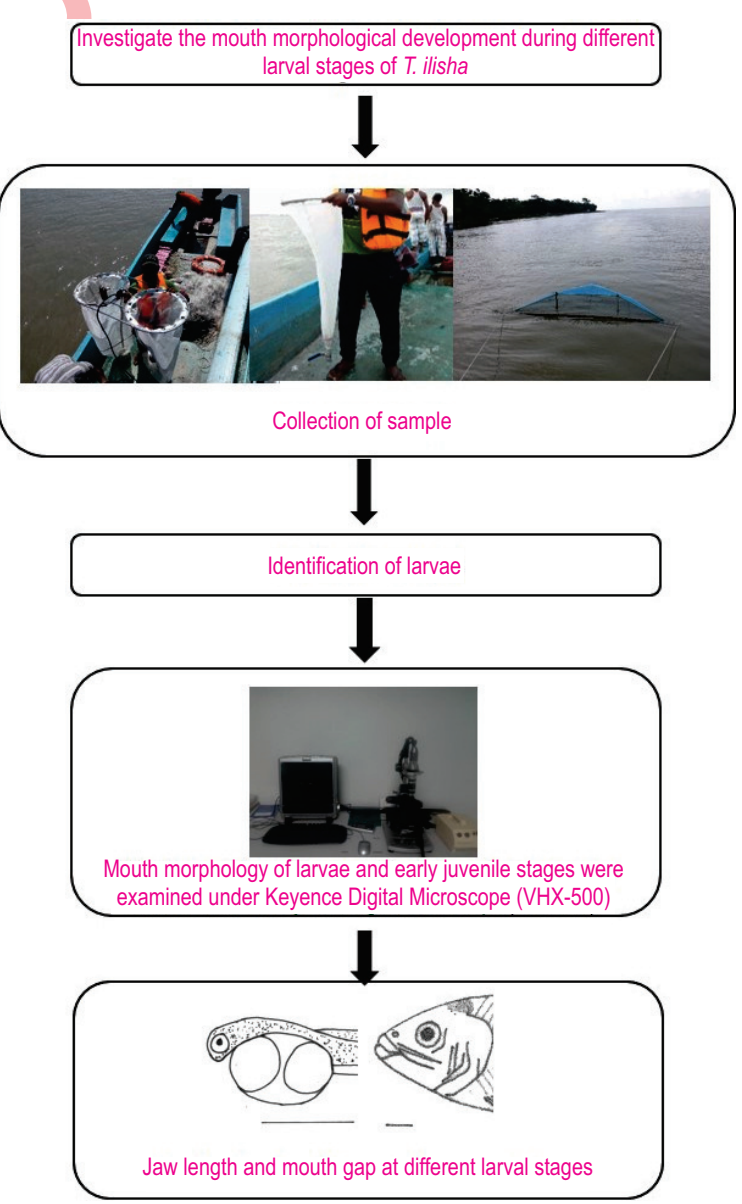




\section{Introduction}

Hilsa Shad, Tenualosa ilisha is found in the open ocean, coastal areas, estuaries and rivers throughout Asia, including Bangladesh, Myanmar, India, Pakistan, Kuwait, Iraq, Iran, Indonesia and Malaysia. T. ilisha is an anadromous species, found to migrate to river as long as more than $1000 \mathrm{~km}$ inland for feeding and breeding (Mohanty et al., 2012). It is an accepted concept by most of fishery researchers that maintenance of larval survival and growth, are primarily determined by the availability of food, especially at the early larval stage and transition period of yolk absorption to exogenous feeding (Fraser, 1970; Cushing, 1975). The transition from endogenous to exogenous feeding is one of the most crucial time (Conides and Glamuzina, 2001; Moteki et al., 2001) and, during this weaning period, mass mortalities have been routinely observed (Kamler, 1992; Haniffa etal., 1999).

Physical morphological changes also play a major role in larval transition period, especially during weaning time (Peter, 1996). Mouth and associated organ development are related with the feed and feeding behavior of the fish, and these parameters can vary substantially among different species. The differences among species in mouth development also play a role in the successful survival of fish larvae (Keast and Webb, 1966). The structure and size of the mouth gap show a close relationship with the ability to consume food particles (Hepher, 1988; Lovell, 1989), and indeed is a limiting factor in larval feeding on either live or artificial diets (Hyatt, 1979). Also, some research findings indicate that mouth gap differences among species is proportionate to the mouth opening and fish length during ontogenic events (Walford and Lam, 1993; Kamali et al., 2006). Hassan and Macintosh (1992) and Dabrowski et al. (1983) also reported the differences in the mouth size among larval fish species including common carp Cyprinus carpio, grass carp Ctenopharyngodon idella, silver carp Hypophthalmichthys molitrix and bighead carp Aristichthys nobilis. Further, they also observed a linear relationship between mouth size and total length of these species.

Various studies have reported the attainment of specific minimum mouth size, i.e., the jaw length and mouth gap, which are mandatory features for effective catching and feeding on food (Economou, 1991; Munk, 1992; Crockford and Johnston, 1993; Bremigan and Stein, 1994). Hence, this study was conducted to understand the mouth development during different larval stages of $T$. ilisha, which might assist in their aquaculture such as choosing the most appropriate live food.

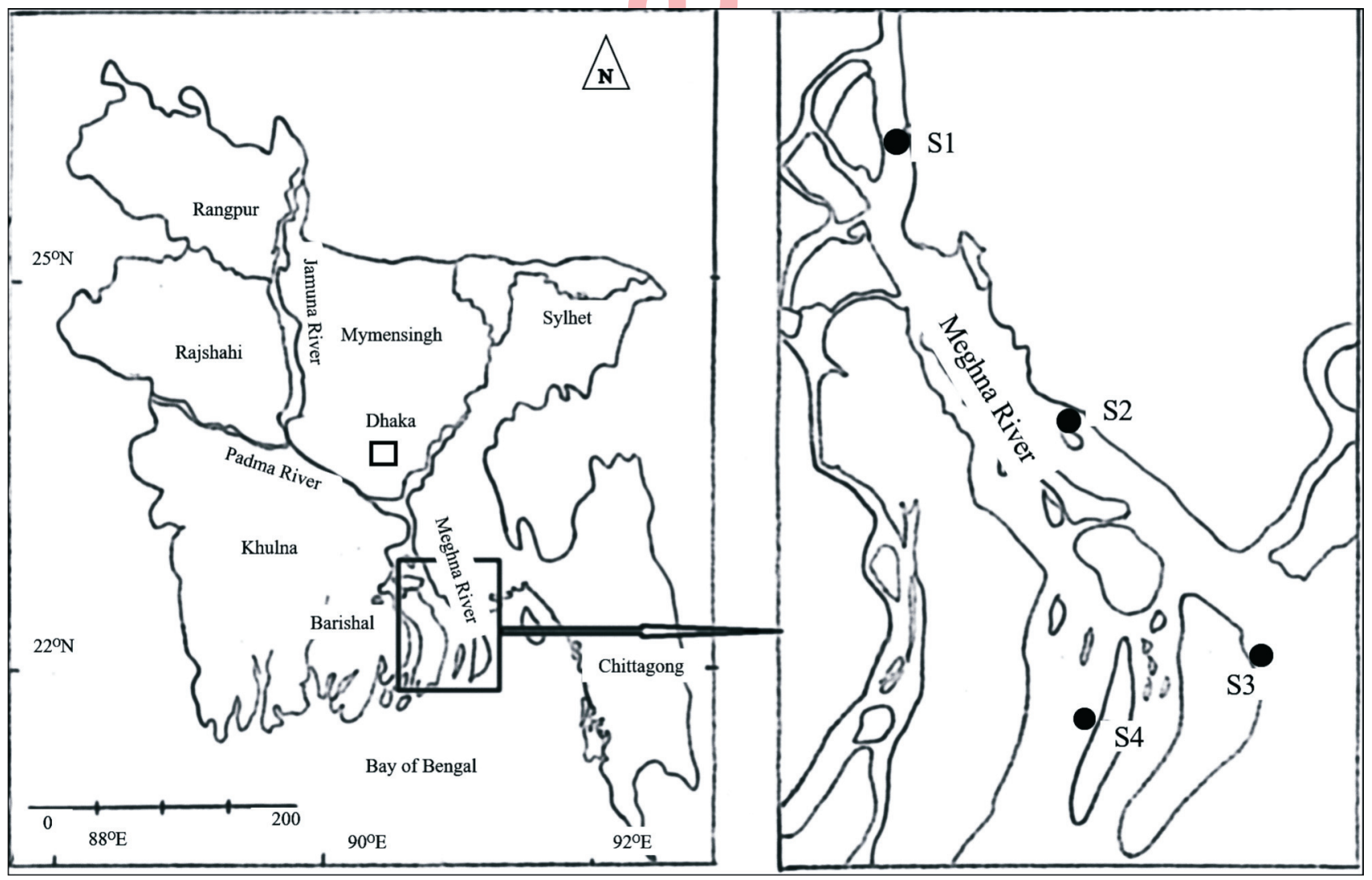

Fig. 1: Location of the sampling stations (dots) in the Meghna river of Bangladesh 


\section{Materials and Methods}

The larvae of $T$. ilisha used in this study were collected from different sites of Meghna estuary between August 2016 and January 2017 on weekly basis (Fig. 1). The location of the sampling stations were S1 (23.084228 N, $90.643853 \mathrm{E})$, upper estuary (Char Bhoirobi, Chandpur District); S2 (22.686959 N, 90.932244 E), middle estuary (Ramgati, Laxmipur District); S3 (22.283453 N, 91.124505 E), lower estuary ((Hatiya, Noakhali District); and S4 (22.266470 N, $90.962331 \mathrm{E})$, lower estuary (Monpura, Bhola District). Water quality parameters of the sampling sites were recorded using a Hach kit from one-meter water depth. Three different types of nets were used for the collection of larvae, they were bongo net (mesh size: $400 \mu$ ), plankton net (mesh size: $200 \mu$ ) and mosquito net (mesh size: 300 $\mu)$. All nets were operated using sub surface tow.

The collected fish larvae were sorted out from other zooplanktons based on the common identification characters of Clupeiformes, such as a long and elongated body with high number of myomeres; long and slightly striated gut; posterior anus, anal fin development just behind the dorsal fin and prenatal length covered more than 2/3 of total length (Silva et al., 2010; Leis and Carson-Ewart, 2000; Leis and Trnski, 1989) using a dissection microscope (Olympus Sz51).

Yolk sac stage larvae were avoided for measuring length because those had no evidence of mouth opening. The morphological development of the mouth and jaw of T. ilisha larvae were observed from preflexion larvae to early juvenile. A total of 87 larvae of the preflexion, flexion, postflexion stages and early juvenile period were measured during microscopic observation. The number of individuals were taken for analysis as follows: pre-flexion larvae $(P F)=15$, flexion larvae $(F L)=24$, post-flexion larvae $(\mathrm{PO})=24$ and juvenile larvae $(\mathrm{JV})=24$. The larvae were taken in a petri dish and its standard length (SL), upper jaw length (UJL) and lower jaw length (LJL) was measured using Keyence Digital Microscope (VHX-500) at 20-30X. A line drawings of the mouth were sketched using the images observed under a microscope. Mouth gape at $45^{\circ}$ (MG45) and Mouth gape at $90^{\circ}\left(\mathrm{Mg} 90^{\circ}\right)$ was determined using the following formulae:

$\operatorname{Mg} 45-\operatorname{Sin} 45^{\circ}{ }^{*} \mathrm{UJL}\left(\operatorname{Sin} 45^{\circ}=0.71\right)$
$\operatorname{Mg} 90-\left\{(U J L)^{\wedge} 2+(L J L)^{\wedge} 2\right\}^{\wedge 11 / 2}$

All slopes of linear equation were tested using simple t-tests.

\section{Results and Discussion}

The results of the water quality analysis ranged in the following manner: air temperature $17-33^{\circ} \mathrm{C}$, water temperature $17-32^{\circ} \mathrm{C}$, transparency $11-90 \mathrm{~cm}$, dissolved oxygen $4-6.5 \mathrm{mg} \mathrm{l}^{-1}$, free $\mathrm{CO}_{2} 10-29.4 \mathrm{mg} \mathrm{l}^{-1}, \mathrm{pH} 7.5-8.5$, total alkalinity $42-121 \mathrm{mg} \mathrm{l}^{-1}$, total hardness $56-142 \mathrm{mg} \mathrm{l}^{-1}$ and salinity $0-2 \mathrm{ppt}$.

The yolk sac larvae ( $3.83 \pm 0.57 \mathrm{SL}$ ) of $T$. ilisha contained a yolk sac consisting of two oil globules. No pigmented eyes were observed and mouth was closed at this stage (Fig. 2a, 2b), but opened during the end of this stage. However, still there was evidence of teeth development at this stage.

Once, the yolk sac was absorbed and pre-flexion appeared (Fig. 2c, 2d), a well-developed esophagus was noticed. Further observations indicated that the upper jaw was shorter than the lower jaw in their well-developed mouth. Their standard length was $8.47 \pm 1.58 \mathrm{~mm}$, while their upper and lower jaw length was $0.25 \pm 0.04 \mathrm{~mm}$ and $0.27 \pm 0.03 \mathrm{~mm}$, respectively (Table 1). The jaw length developed in accordance with the standared length of larvae. The size of mouth gape was $177 \pm 25 \mu \mathrm{m}$ at $45^{\circ}$ of the mouth opening, whereas the mouth gape was found $367 \pm$ $47 \mu \mathrm{m}$ at $90^{\circ}$ of mouth opening.

At the flexion stage (Fig. 2e, 2f), the standard length of larvae was $11.50 \pm 1.55 \mathrm{~mm}$ and its upper and lower jaw length was $0.34 \pm 0.04 \mathrm{~mm}$ and $0.36 \pm 0.04 \mathrm{~mm}$, respectively (Table 1 ). At this stage, the digestive system, as well as an active operational mouth of the larvae was well developed. During this stage, the mouth opening of the larvae at $45^{\circ}$ and $90^{\circ}$ was $241 \pm$ 31 and $497 \pm 59 \mu \mathrm{m}$, respectively.

At the post-flexion stage (Fig. 2g, 2h), the standard length of larvae was $14.72 \pm 1.70 \mathrm{~mm}$, while its corresponding upper jaw and lower length was $0.43 \pm 0.05 \mathrm{~mm}$ and $0.45 \pm 0.05 \mathrm{~mm}$, respectively (Table 1). Similar to the flexion stage, the length of the mouth opening at $45^{\circ}$ and $90^{\circ}$ was $307 \pm 38$ and $621 \pm 74 \mu \mathrm{m}$, respectively.

Table 1: Mean standard length (SL), upper jaw (UJ), lower jaw (LJ) and mouth gape (MG) at $45^{\circ}$ and $90^{\circ}$ of $T$. ilisha larvae and juvenile*

\begin{tabular}{|c|c|c|c|c|c|}
\hline Development Stage & $\mathrm{SL}(\mathrm{mm})$ & UJL (mm) & LJL (mm) & $M G 45^{\circ}(\mu \mathrm{m})$ & MG $90^{\circ}(\mu \mathrm{m})$ \\
\hline Yolk sac & $3.83 \pm 0.57$ & $* *$ & ** & $* *$ & ** \\
\hline Pre-flexion & $8.47 \pm 1.58$ & $0.25 \pm 0.04$ & $0.27 \pm 0.03$ & $177 \pm 25$ & $367 \pm 47$ \\
\hline Flexion & $11.50 \pm 1.55$ & $0.34 \pm 0.04$ & $0.36 \pm 0.04$ & $241 \pm 31$ & $497 \pm 59$ \\
\hline Post-flexion & $14.72 \pm 1.70$ & $0.43 \pm 0.05$ & $0.45 \pm 0.05$ & $307 \pm 38$ & $621 \pm 74$ \\
\hline Juvenile & $18.80 \pm 3.12$ & $0.55 \pm 0.09$ & $0.56 \pm 0.08$ & $393 \pm 61$ & $788 \pm 119$ \\
\hline
\end{tabular}

* SL, UJL and LJL expressed in mm, while MG expressed in micron $(\mu \mathrm{m})$ as mean values \pm S.D.; ** $=$ Not opened 

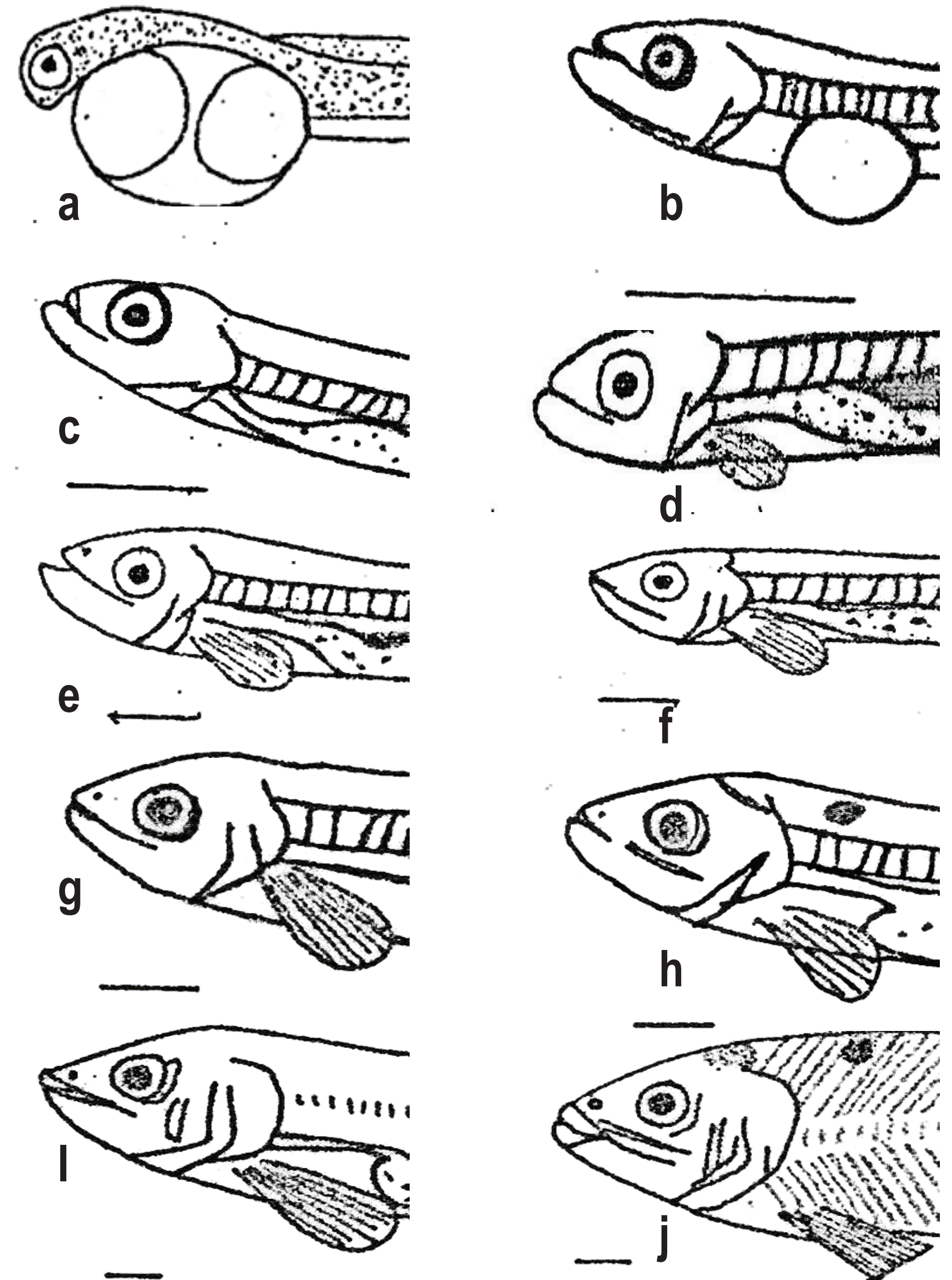

Fig. 2: Mouth morphological development of $T$. ilisha larvae and juvenile. Yolk sac stage $(a, b)$, pre-flexion stage $(c, d)$, flexion stage (e,f), post- flexion stage $(\mathrm{g}, \mathrm{h})$ and juvenile stage $(\mathrm{i}, \mathrm{j})$. Bar $=1 \mathrm{~mm}$ 
At juvenile stage (Fig. 2i, 2j), the larval external morphology was almost similar to an adult individual and it's SL = $18.80 \pm 3.12 \mathrm{~mm}$. The upper $(0.55 \pm 0.09 \mathrm{~mm})$ and lower $(0.56 \pm$ $0.08 \mathrm{~mm}$ ) jaws, as well as its mouth were shorter in size (Table 1 ). The jaw extended upto in front of eye. In this stage, the mouth opening length at 45 and $90^{\circ}$ was $393 \pm 61$ and $788 \pm 119 \mu \mathrm{m}$, respectively. Overall, from the data analysis, there was a strong relation between standard length (SL) with the upper jaw length (UJL), lower jaw length (LJL), mouth gape at $45^{\circ}\left(\mathrm{Mg}^{\circ} 5^{\circ}\right.$ ) and

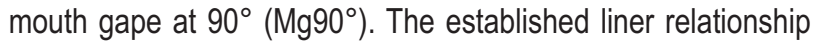
models are given below:

$U J L=0.281+S L^{*} 0.0329\left(R^{2}=0.941, p<0.05 ;\right.$ Fig. 3$)$

$L J L=0.0274+S L^{*} 0.0634\left(R^{2}=0.931, p<0.05 ;\right.$ Fig. 4)

$M G 45^{\circ}=19.965+S L^{*} 23.394\left(R^{2}=0.941, p<0.05 ;\right.$ Fig. 5$)$

$M G 90^{\circ}=39.21+S L^{*} 68.658\left(R^{2}=0.939, p<0.05 ;\right.$ Fig. 6$)$

In the case of yolk-sac larvae, the total length were $4.20 \pm$ $0.64 \mathrm{~mm}$ while Kulkarni (1950) observed 2.3 to $3.1 \mathrm{~mm}$ total length for hatchlings. There were two oil globules observed at this stage, while Kulkarni (1950) observed three oil globules for newly

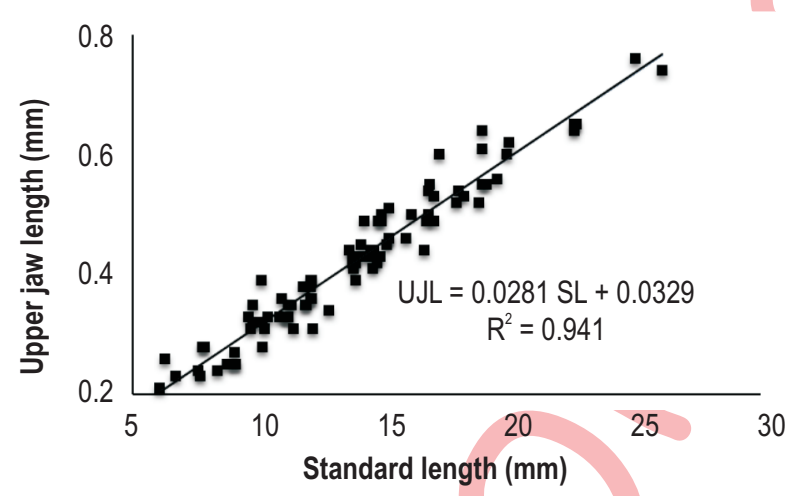

Fig. 3 : A linear relationship between upper jaw length (UJL) and standard length $(\mathrm{SL})$ of $T$. ilisha larvae $(\mathrm{UJL}=0.281 \mathrm{SL}+0.0329)$

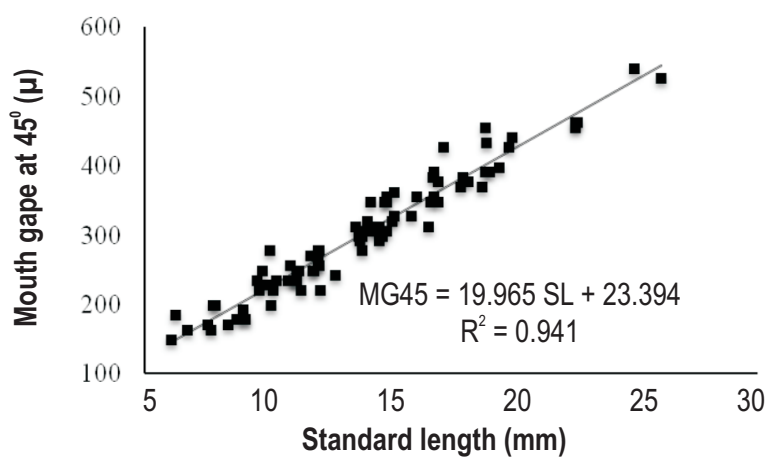

Fig. 5 : A linear relationship between mouth gape at $45^{\circ}\left(\mathrm{Mg} 45^{\circ}\right)$ and standard length $(\mathrm{SL})$ of $T$. ilisha larvae $\left(\mathrm{Mg} 45^{\circ}=19.965 \mathrm{SL}+23.394\right)$ hatched larvae. In this study, there was no pigmentation in eye and mouth was close at the yolk sac larvae and the same observation was found with Anchoviella vaillanti larvae (Silva et al., 2010).

Just after yolk sac absorption, the mouth of the larvae opened and the larvae started exogenous feeding, which is an essential transition to support faster growth (Scharf et al., 2000; Aljetlawi et al., 2004). Jaw length and mouth gape has a close relationship in picking the food particles (Hepher, 1988). This study found that smallest food size equal to the mouth gap $45^{\circ}$ while the largest size equal to the $90^{\circ}$ of mouth opening (Hag et al., 2012). In this study, the size of mouth gap was $177 \pm 25 \mu$ at $45^{\circ}$ of mouth opening whereas the mouth gap was found $367 \pm 47$ $\mu$ at $90^{\circ}$ of mouth opening at pre flexion stage. So the minimum food size was equal to $177 \pm 25 \mu \mathrm{m}$, while the maximum size of food particle equaled $367 \pm 47 \mu$ for $T$. ilisha larvae at the preflexion stage. With increasing growth, and thus mouth gape, the size of the food particles can also increase in $T$. ilisha juveniles (Hasan et al., 2016). The consistently longer lower jaw indicates larvae are surface feeders, which is in agreement with the suggestion of Hasan et al. (2016). However, because there was no evidence of teeth it is assumed that $T$. ilisha is a non-predatory

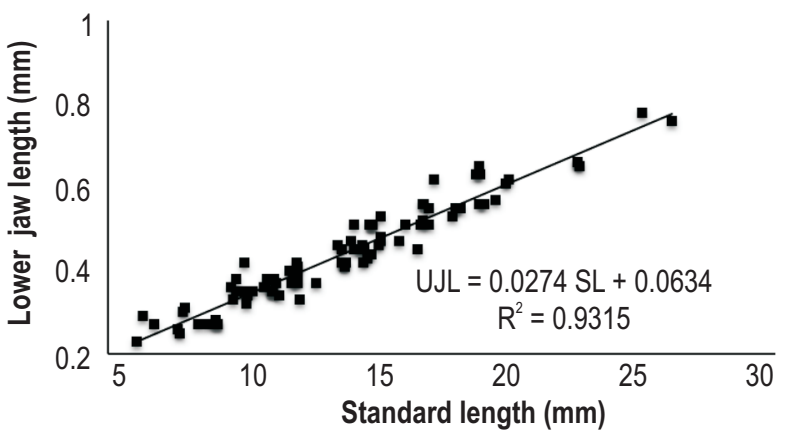

Fig. 4 : A linear relationship between lower jaw length (UJL) and standard length $(\mathrm{SL})$ of $T$. ilisha larvae $(\mathrm{LJL}=0.0274 \mathrm{SL}+0.0634)$

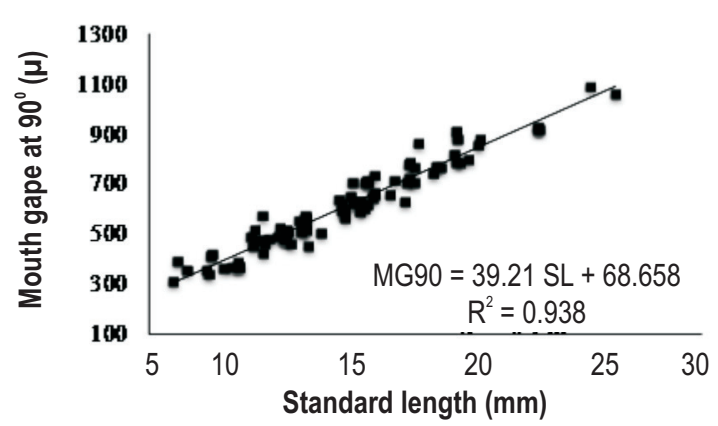

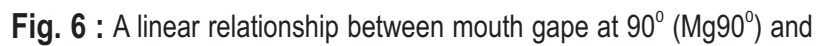
standard length $(\mathrm{SL})$ of $T$. ilisha larvae $\left(\mathrm{Mg} 90^{\circ}=39.21 \mathrm{SL}+68.658\right)$ 
fish. Indeed, Hasan et al. (2016) described T. ilisha as herbivorous in nature and depend mainly on phytoplankton for feeds.

Overall, this study showed that exogenous feeding only began after yolk-sac absorption and their first live food should be small such as rotifers or Daphnia sp. Considering the high commercial importance of $T$. ilisha, further research into their larviculture techniques should be conducted. This can include optimal environmental conditions and feeding regimes.

\section{Acknowledgments}

This paper is a part of Master thesis. Financial contribution from EcoFish project of WorldFish, South Asia, Bangladesh. We are grateful to Dr. Anisur Rahman and Dr. Jalilur Rahman for their cooperation during field sampling.

\section{References}

Aljetlawi, A.A., E. Sparrevik and K. Leonardsson: Prey-predator sizedependent functional response: Derivation and rescaling to the real world. J. Animal Ecol., 73, 239-252. (2004).

Bremigan, M.T. and R.A. Stein: Gape-dependent larval foraging and zooplankton size: Implications for fish recruitment across systems. Can. J. FishAquat. Sci., 51, 913-922 (1994).

Conides, A.J. and B. Glamuzina: Study on the early larval development and growth of red progy, Pagrus pagrus with emphasis on the mass mortalities observed during this phase. Sci. Mar., 65, 193200 (2001).

Crockford, T. and I.A. Johnston: Developmental changes in the composition of myofibrillar proteins in the swimming muscles of Atlantic herring. Clupea harengus. Mar. Biol., 115, 15-22 (1993).

Cushing, D.H: Marine Ecology and Fisheries. Cambridge University Press, Cambridge, UK. (1975).

Dabrowski, K., R. Bardega and R. Przedwojski: Optimum particle size in relation to body size of common carp, Cyprinus carpio $L$. fry. Aquacult. Fish. Manage., 23, 315-325. (1983).

Economou, A.N.: Food and feeding ecology of five gadoid larvae in the Northern North Sea. J. Cons. Int. Explor. Mer., 47, 339-351 (1991).

Fraser, J.H.: The ecology of the ctenophore Pleurobrachia pileus in Scottish waters. ICES J. Cons., 33, 149-168 (1970).

Hag, G.A.E., M.S. Kamarudin, C.R. Saad and S.K. Daud: Mouth development of Malaysian river catfish, Mystus nemurus (C\&V) larvae. J. Amer. Sci., 8, 271-276. (2012).

Haniffa, M.A., A.J. Arockiaraj and S. Sridhar: Weaning diet for striped murrel Channa striatus. Fish. Technol., 36, 116-119 (1999).

Hasan, K.M.M., Z.F. Ahmed, M.A. Wahab and E.Y. Mohammed: Food and feeding ecology of hilsa (Tenualosa ilisha) in Bangladesh's Meghna River basin. IIED Working Paper. IIED, London (2016).

Hassan, M.A. and D.J. Macintosh: Optimum food particle size in relation to body size of common carp (Cyprinus carpio) fry. Aquacult. Fish.
Manage. 23, 315-325(1992).

Hepher, B.: The alimentary canal. In: Nutrition of pond fishes (Eds.: H. J. Schoonbee, R. J. Roberts, K. Jauncay and M. Beveridage), 23, 1845-1874 (1988).

Hyatt, K.D.: Feeding strategy. In: Fish physiology (Eds.: W. S. Hoav D. J. Randall and J. R. Brett), pp. 77-119 (1979).

Kamali, A., Z. Kordjazi and R. Nazary: The effect of the timing of initial feeding on growth and survival of ship sturgeon (Acipenser nudiventris) larvae: A small-scale hatchery study. J. Appl. Ichthyol., 22, 294-297 (2006).

Kamler, E.: Early life history of fish. An energetic approach. Chapman \& Hall, London, p. 183 (1992).

Keast, A. and D. Webb: Mouth and body form relative to feeding ecology in the fish fauna of small lake, Lake Opinicon, Ontario. J. Fish. Res. Board, 23, 1845-1874 (1966).

Kulkarni, C. V.: Breeding habits, eggs and early life history of Indian Shad, Hilsa iliaha (Ham), in Narbad River. Zoological Survey of India, 169-170 (1950).

Leis, J.M. and B.M. Carson-Ewart: The larvae of Indo-Pacific coastal fishes: An Identification Guide to Marine Fish Larvae. Australian Museum, Sydney, pp. 67-69(2000)

Leis, J.M. and T. Trnski: The larvae of Indo-Pacific shore fishes. New South Wales University Press, Sydney and University of Hawaii Press, Honolulu, p. 371 (1989).

Lovell, R.T.: Digestion and Metabolism. In Nutrition and Feeding of Fish (Eds.: H. Ronald and L. Chorn), Van Nostrand Reinhold. New York. pp.73-80 (1989).

Mohanty, B. P., P. Paria, A. Mahanty, B. K. Behera, S. Mathew, T. V. Shankar and A. P. Sharma: Fatty acid profile of Indian Shad Tenualosa ilisha oil and its dietary significance. Nat. Acad. Sci. Lett., 35, 263-269 (2012).

Moteki, M., T. Ishikawa, N. Teraoka and H. Fushimi: Transition from endogenous to exogenous nutritional sources in larval sea bream, Pagrus major. Suisanzoshoku, 49, 323-328. (2001).

Munk, P.: Foraging behaviour and prey size spectra of larval herring Clupea harenqus. Mar. Ecol. Prog. Ser., 80, 149-158 (1992).

Peter, C.W.: Ecology explanation through functional morphology: The feeding biology of sun fishes. Ecology, 77, 1336-1343 (1996).

Robb, A.P. and J.R.G. Hislop: The food of five gadoid species during the pelagic O-group phase in the Northern North Sea, J. Fish Biol., 16, 199-217 (1980).

Scharf, F.S., F. Juanes and R.A. Rountree: Predator size-prey size relationships of marine fish predators: interspecific variation and effects of ontogeny and body size on trophic-niche breadth. Mar. Ecol. Prog. Ser., 208, 229-248 (2000).

Silva, A.C.G.D., W. Severi and F.C. Maviael: Morphological development of Anchoviella vaillanti (Steindachner, 1908) (Clupeiformes: Engraulidae) larvae and early juveniles. Neotrop. Ichthyol., 8, 805$812(2010)$.

Walford, J. and T.J. Lam: Development of digestive tract and proteolytic enzyme activity in seabass (Lates calcarifer) larvae and juveniles. Aquaculture, 109, 187-205(1993). 